\title{
Metagenomic Analysis of Microbial Community Compositions and Cold-Responsive Stress Genes in Selected Antarctic Lacustrine and Soil Ecosystems
}

\author{
Hyunmin Koo ${ }^{1, *(\mathbb{D})}$, Joseph A. Hakim ${ }^{1}$, Casey D. Morrow ${ }^{2}$, Michael R. Crowley ${ }^{3}$, \\ Dale T. Andersen ${ }^{4}(\mathbb{D})$ and Asim K. Bej ${ }^{1, *}$ \\ 1 Department of Biology, University of Alabama at Birmingham, Birmingham, AL 35294, USA; joe21@uab.edu \\ 2 Department of Cell, Developmental and Integrative Biology, School of Medicine, \\ University of Alabama at Birmingham, Birmingham, AL 35294, USA; caseym@uab.edu \\ 3 Department of Genetics, Heflin Center Genomics Core, School of Medicine, \\ University of Alabama at Birmingham, Birmingham, AL 35294, USA; mcrowley@uab.edu \\ 4 Carl Sagan Center, SETI Institute, Mountain View, California, CA 94043, USA; dandersen@seti.org \\ * Correspondence: khmkhm87@uab.edu (H.K.); abej@uab.edu (A.K.B); Tel.: +1-205-934-9857 (A.K.B)
}

Received: 16 June 2018; Accepted: 9 July 2018; Published: 11 July 2018

check for updates

\begin{abstract}
This study describes microbial community compositions, and various cold-responsive stress genes, encompassing cold-induced proteins (CIPs) and cold-associated general stress-responsive proteins (CASPs) in selected Antarctic lake water, sediment, and soil metagenomes. Overall, Proteobacteria and Bacteroidetes were the major taxa in all metagenomes. Prochlorococcus and Thiomicrospira were highly abundant in waters, while Myxococcus, Anaeromyxobacter, Haliangium, and Gloeobacter were dominant in the soil and lake sediment metagenomes. Among CIPs, genes necessary for DNA replication, translation initiation, and transcription termination were highly abundant in all metagenomes. However, genes for fatty acid desaturase (FAD) and trehalose synthase (TS) were common in the soil and lake sediment metagenomes. Interestingly, the Lake Untersee water and sediment metagenome samples contained histone-like nucleoid structuring protein (H-NS) and all genes for CIPs. As for the CASPs, high abundances of a wide range of genes for cryo- and osmo-protectants (glutamate, glycine, choline, and betaine) were identified in all metagenomes. However, genes for exopolysaccharide biosynthesis were dominant in Lake Untersee water, sediment, and other soil metagenomes. The results from this study indicate that although diverse microbial communities are present in various metagenomes, they share common cold-responsive stress genes necessary for their survival and sustenance in the extreme Antarctic conditions.
\end{abstract}

Keywords: MG-RAST; cold shock; Lake Untersee; Ace Lake; Newcomb Bay Lake; Mount Seuss; McMurdo Dry Valleys

\section{Introduction}

The geophysical transformation accompanied by climatic changes during the Earth's evolution for the last $\sim 4$ billion years resulted in the establishment of a wide range of ecosystems on this planet, and various lines of evidence suggest that microbial life has existed and evolved during the last $\sim 3.5$ billion years of Earth's history [1,2]. These ecosystems, diverse in their physicochemical properties and changing over time, have required that life develop novel metabolic strategies for the exploitation of the numerous niches available across the planet. The functioning of microorganisms at the cellular and community levels is constrained by a set of physicochemical parameters within the ecosystems they inhabit [3]. Some of these ecosystems are categorized as "extreme habitats" where the inhabiting organisms have adapted to environmental parameters often considered inimical to the maintenance 
of life-functions for others [4]. Given that over $70 \%$ of Earth maintains near- or below-freezing temperatures, the cold ecospheres constitute the largest "physical extremes" for microbial communities to inhabit, manifest adaptive attributes, and drive key biological and geochemical processes $[5,6]$.

Within the cryosphere, the Antarctic continent offers perennially cold, subzero temperatures as well as other challenges, such as oligotrophy, intense winds, aridity, and high solar UV radiation (during the austral summer months). Thus, all organisms, including microorganisms, living on this icy continent must possess various adaptive traits to sustain life [7]. Early studies of soil microbiology in the McMurdo Dry Valleys relied upon culture-dependent methods [8], however the diversity and distribution of microorganisms in various Antarctic ecosystems were not more fully explored until the advent of DNA-based culture-independent methods [5-7,9-15]. Recently, the applications of shotgun sequencing of the metagenome have enabled the elucidation of both taxonomic identities as well as crucial adaptive genetic traits necessary for microorganisms to cope with the environmentally imposed physical and nutritional extremes on this icy continent [16-21].

Although about $98 \%$ of the Antarctic landmass is covered by an ice sheet with a mean thickness of $2.16 \mathrm{~km}$ (maximum thickness up to $\sim 4.78 \mathrm{~km}$ ), a number of ice-free "oases" exist where various open-water lakes, perennially-ice covered lakes, and ponds largely support life [22,23]. Among these lakes, the perennially ice-covered lakes are particularly interesting to explore microbial communities and their adaptive strategies due to their unique physical, chemical, and limnological features [24]. The permanent ice cover $(\sim 3-5 \mathrm{~m})$ of these lakes restricts wind-driven mixing of the water column, exchange of atmospheric gases, deposition of sediments, and light penetration $[25,26]$. In addition, most of these lakes manifest a stable water column with strong chemical stratification and minimal vertical mixing $[27,28]$. Lake Untersee is one of the largest $\left(11.4 \mathrm{~km}^{2}\right)$ and deepest $(>160 \mathrm{~m})$ perennially ice-covered ultraoligotrophic freshwater lakes in Antarctica. This lake is located in the Grüber Mountains of Central Queen Maud Land in East Antarctica and is partly dammed by the Anuchin Glacier [29-32]. The water column in Lake Untersee is well-mixed due to the temperature gradient ( $\sim{ }^{\circ} \mathrm{C}$ on the top and $4{ }^{\circ} \mathrm{C}$ at the bottom) [29], contains a high concentration (150\%) of dissolved oxygen, and harbors benthic photosynthetic microbial mats [30]. In addition, the high $\mathrm{pH}$ gradient, ranging between 9.8 and 12.1, unusual dynamics of temperature and water circulation, high methane content in some locations, and ultraoligotrophic conditions offer unique challenges to the microbial communities in this lake $[29,30,33]$.

In this study, we have used the shotgun metagenomics approach along with bioinformatics tools to explore the microbial community compositions and genetic signatures for cold-responsive genes that code for cold-induced proteins (CIPs) and cold-associated general stress-responsive proteins (CASPs) in microbial communities of Lake Untersee water and sediment samples. In addition, we have used seven publicly available shotgun metagenome datasets of various other Antarctic lake and soil samples to compare and contrast the metagenomic profile of microbial communities and cold-responsive stress genes in Lake Untersee water and sediment samples.

\section{Materials and Methods}

\subsection{Sample Collection}

Lake Untersee water samples were collected from the south basin at a depth of $80 \mathrm{~m}\left(71.35609^{\circ} \mathrm{S}\right.$, $13.4268^{\circ}$ E) (Figure 1) using a $2.2 \mathrm{~L}$ acrylic Kemmerer bottle (Wildco, Yulee, FL, USA) via $25 \mathrm{~cm}$ holes drilled through the ice-cover. These samples were then filtered using cellulose nitrate membrane filters (Whatman, $47 \mathrm{~mm} \times 0.2 \mu \mathrm{m}$ ) (membrane filters herein) to obtain cells for DNA extraction. The lake sediment samples were collected at a depth of $15 \mathrm{~m}\left(71.34197^{\circ} \mathrm{S}, 13.45458^{\circ} \mathrm{E}\right)$ by inserting 50- or 100 $\mathrm{mm}$ diameter polycarbonate core tubes into the lake floor, gently removing them without disturbance, sealing them with rubber stoppers, and then returning them to the surface. Samples were then divided into $1 \mathrm{~cm}$ sections, preserved, and stored as stated above. The collection of sediment samples was conducted by scientific divers via a dive hole $\left(71.34197^{\circ} \mathrm{S}, 13.45458^{\circ} \mathrm{E}\right)$ on the lake using the techniques 
developed for studies of Antarctic lakes [34]. Immediately after collection, the water and sediment samples were preserved in $70 \%$ ethanol, first at $-20^{\circ} \mathrm{C}$ and then at $-80^{\circ} \mathrm{C}$, at the Antarctic Logistics Centre International (ALCI), Cape Town, South Africa facility. Then, samples were transported to University of Alabama at Birmingham (UAB) in dry ice and kept at $-80^{\circ} \mathrm{C}$ until further use.

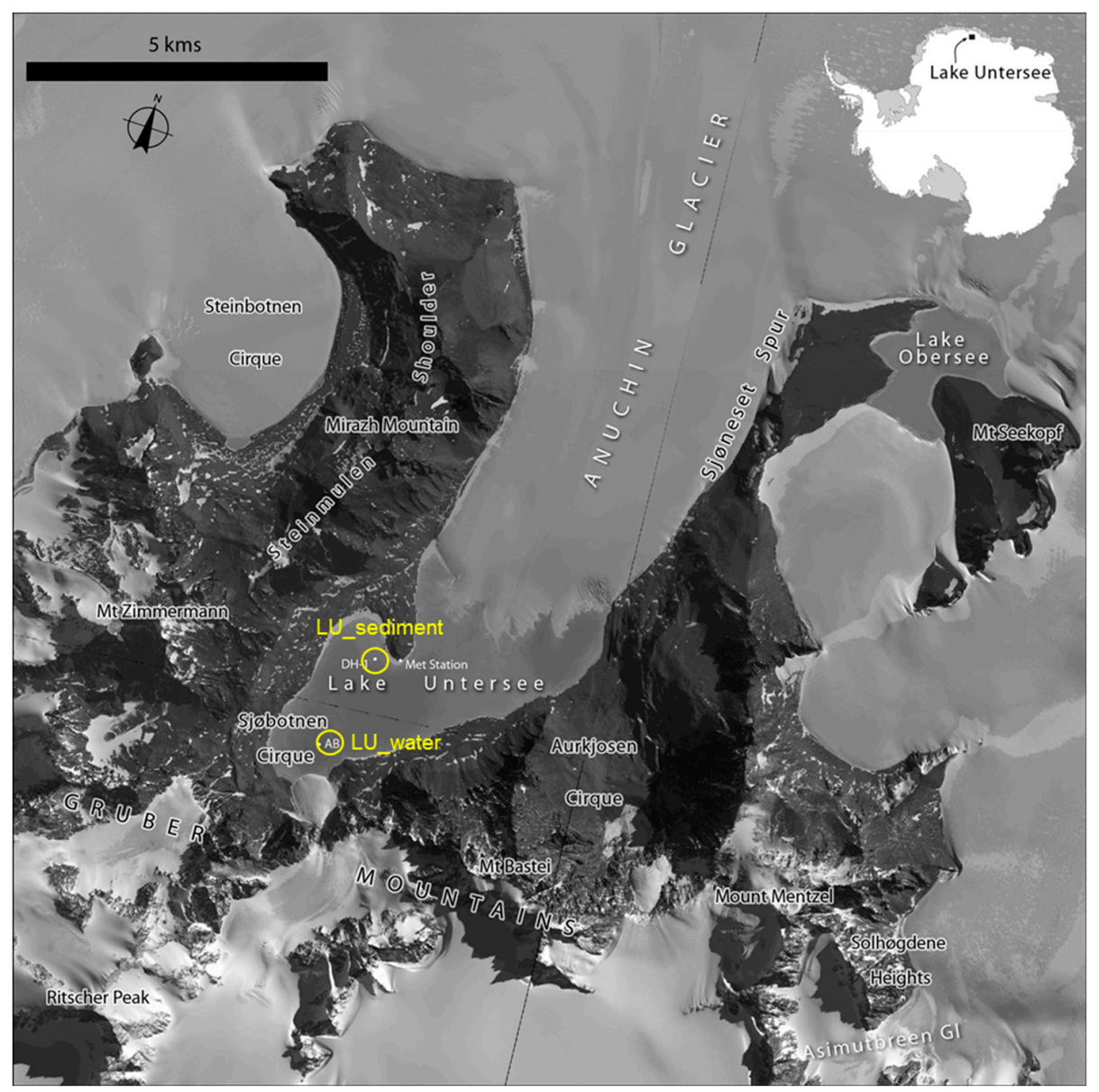

Figure 1. Satellite image map of Lake Untersee. Satellite imagery copyright DigitalGlobe, Inc. and provided by the NGA Commercial Imagery Program. The locations for the Lake Untersee water (LU_water) and sediment (LU_sediment) metagenomes are shown (circles).

A total of seven publicly available Antarctic metagenome datasets were downloaded from the Metagenomics Analysis Server (MG-RAST) [35,36] and then used to filter the CIPs and CASPs. The metagenome dataset used in our study was derived from (1) water metagenomes from Ace Lake $(n=1)$ and Newcomb Bay Lake $(n=1)$; and (2) soil metagenomes from Mount Seuss $(n=1)$ and McMurdo Dry Valleys $(n=4)$. Out of the four McMurdo Dry Valleys metagenomes, three were from the Taylor Valley floor adjacent to Lake Hoare, Lake Bonney, and Lake Fryxell, whereas the fourth sample was from Wright Valley. For simplicity of the data analysis and description, we have used the following designation of the metagenomes: AL_water for Ace Lake water; NB_water for Newcomb Bay Lake water; MS_soil for Mount Seuss soil; and MDV_soil for McMurdo Dry Valleys soil (Table 1). For Lake Untersee water $(n=1)$ and sediment $(n=1)$ metagenomes, we have used LU_water and LU_sediment, respectively.

\subsection{DNA Extraction and Sequencing}

Purification of community DNA from LU_water and LU_sediment samples was carried out by using sterilized scalpels, separate pipettes, and separate fresh reagents to avoid cross contamination. 
The LU_sediment samples (1 g each) and the membrane filters were subjected to DNA extraction by using the MoBio PowerSoil ${ }^{\circledR}$ DNA Isolation Kit (MoBio Laboratories Inc., Carlsbad, CA, USA; cat \# 12888-100). Briefly, each sample was transferred into separate $2 \mathrm{~mL}$ PowerBead tubes and then used for community DNA extraction. The purified DNA in triplicate was pooled into a single sample to obtain enough DNA that collectively represented the microbial community composition in the LU_water and LU_sediment samples $[37,38]$. The quality and concentration of the pooled DNA from each water and sediment sample was determined by using a Lambda II spectrophotometer (Perkin Elmer, Norwalk, Conn.) followed by agarose gel electrophoresis (1\% wt/vol agarose in $1 \mathrm{X}$ Tris-Acetate-EDTA (TAE) buffer, pH 7.8) [39]. Then, the purified DNA samples were dried in a Savant Speedvac Evaporator SVC $100 \mathrm{H}$ and stored at $4{ }^{\circ} \mathrm{C}$ until further use for NGS. All prepared samples were subjected to shotgun metagenomics sequencing on the Illumina HiSeq platform (paired-end, 2 by $101 \mathrm{bp}$ ) at the UAB Heflin Center for Genomic Science (http:/ / www.uab.edu/hcgs/).

Table 1. Antarctic metagenomics sample information used in this study. Included in the table is the location of sampling, sample type reflecting the environment of the collection, the total annotated sequence reads in each sample found in the Metagenomics Analysis Server (MG-RAST), and the MG-RAST ID number.

\begin{tabular}{|c|c|c|c|c|c|}
\hline Samples & Location & Sample Type & $\begin{array}{l}\text { Total Annotated } \\
\text { Sequence Reads }\end{array}$ & MG-RAST ID & Reference \\
\hline Lake Untersee & $71.35609^{\circ} \mathrm{S} 13.4268^{\circ} \mathrm{E}$ & Freshwater & 96,838 & This study & This study \\
\hline Ace Lake & $68.47^{\circ} \mathrm{S} 78.18^{\circ} \mathrm{E}$ & $\begin{array}{c}\text { Saline water } \\
\text { (originally freshwater) }\end{array}$ & 114,319 & $\operatorname{mgm} 4443684.3$ & {$[40,41]$} \\
\hline Newcomb Bay Lake & $66.27^{\circ} \mathrm{S} 110.53^{\circ} \mathrm{E}$ & Marine habitat water & 80,924 & mgm4443686.3 & [42] \\
\hline Lake Untersee & $71.34197^{\circ} \mathrm{S} 13.45458^{\circ} \mathrm{E}$ & Sediment & 119,907 & This study & This study \\
\hline Mount Seuss & $77.02^{\circ} \mathrm{S} 161.85^{\circ} \mathrm{E}$ & Soil & 91,656 & mgm4667023.3 & [43] \\
\hline $\begin{array}{l}\text { McMurdo Dry } \\
\text { Valleys }\end{array}$ & $\begin{array}{l}77.63^{\circ} \mathrm{S} 162.88^{\circ} \mathrm{E}^{1} \\
77.73^{\circ} \mathrm{S} 162.31^{\circ} \mathrm{E}^{2} \\
77.60^{\circ} \mathrm{S} 163.25^{\circ} \mathrm{E}^{3} \\
77.53^{\circ} \mathrm{S} 161.70^{\circ} \mathrm{E}^{4}\end{array}$ & $\begin{array}{l}\text { Soil } \\
\text { Soil } \\
\text { Soil } \\
\text { Soil }\end{array}$ & $\begin{array}{l}27,582 \\
25,064 \\
18,398 \\
24,184\end{array}$ & $\begin{array}{l}\text { mgm4575389.3 } \\
\text { mgm4575387.3 } \\
\text { mgm4575388.3 } \\
\text { mgm4575390.3 }\end{array}$ & [44] \\
\hline
\end{tabular}

${ }^{1}$ Taylor Valley floor adjacent to Lake Hoare; ${ }^{2}$ Taylor Valley floor adjacent to Lake Bonney; ${ }^{3}$ Taylor Valley floor adjacent to Lake Fryxell; and ${ }^{4}$ Wright Valley.

\subsection{Sequence Reads Processing Using Bioinformatics Tools}

Raw sequence reads from the LU_water and LU_sediment samples were quality-checked and then filtered to remove sequence reads shorter than $50 \mathrm{bp}$ and reads with an average quality score less than phred 20 using FASTX-Toolkit (http://hannonlab.cshl.edu/fastx_toolkit/), SICKLE [45], and FastQC [46]. The filtered sequences were then assembled into contigs using IDBA-UD [47] with default parameters followed by assembly quality checking using QUAST [48]. For protein annotation, the resulting sets of contigs were submitted to MG-RAST using their default quality control parameters and subjected to a similarity search using the SEED database [49] keeping $10^{-5}$ as the maximum E-value.

The other seven publicly available Antarctic metagenome datasets used in this study (Table 1) were previously sequenced, preprocessed, assembled, and uploaded into the MG-RAST server by other investigators (Table 1). The specific sequence analysis and/or processing information for these datasets was reported by other investigators (see references in Table 1).

\subsection{Filtering Cold-Induced and Cold-Associated General Stress-Responsive Proteins Using R Code}

All annotated metagenomics datasets, including LU_water and LU_sediment, were used to filter a total of 36 CIPs and CASPs (Table 2). To filter the aforementioned protein sequences from these metagenomics datasets, a user-defined $R$ code [18] was used with specific parameters ( $>10$ alignment 
lengths, $>65 \%$ sequence identity to a subsystem, and E-value $\left.\leq 10^{-5}\right)$. After filtering, the total number of CIPs and CASPs was listed using Microsoft Excel software (Microsoft, Seattle, WA, USA) (Table 2).

\subsection{Comparison of the Taxonomic Distribution and the Filtered Protein Sequences Using Bioinformatics Tools}

Taxonomic profiles at the phylum level, including the domains Archaea, Bacteria, Eukaryota, and viruses across all samples, were assigned against the SEED database [49] using MG-RAST with specific parameters ( $>10$ alignment lengths, $>65 \%$ sequence identity to a subsystem, and E-value $\leq 10^{-5}$ ) and then downloaded for further analyses. The distribution and abundance of all taxonomic information was then visualized in a stacked column bar graph using Microsoft Excel software (Microsoft, Seattle, WA, USA.). In order to obtain certain taxa (at the genus level) contributing to statistical significance variation between the combined soil and lake sediment group (MS_soil, MDV_soil, LU_sediment) and the water group (LU_water, AL_water, and NB_water), we conducted a two-sided Welch's $t$-test [50] with no correction and 95\% confidence intervals with default parameters and then visualized the results in an extended error plot using STAMP analytical software [51].

Distribution and abundance of the filtered CIPs and CASPs across all samples were compared by constructing multidimensional-scaling (MDS) plots [52-54]. Subsequently, a complete linkage hierarchical clustering dendrogram $[53,55,56]$ was constructed following the Bray-Curtis similarity values [57] using PRIMER-6 software (Primer-E Ltd., Ply-mouth Marine Laboratory, Plymouth UK, v6.1.2). Multiple group comparison of all filtered CIPs and CASPs along with their upper hierarchical SEED categories was carried out through the heatmap function implemented in STAMP [51] along with the average neighbor (UPGMA) method with default parameters.

\section{Results}

\subsection{Total Sequence Reads}

Shotgun metagenomics sequencing resulted in a total of 23,981,221 raw sequence reads from the LU_water metagenome and 14,895,305 from the LU_sediment metagenome. Quality assessment and trimming processes produced 23,245,003 sequences reads from LU_water and 14,399,372 from LU_sediment. Preprocessed sequence reads were assembled and annotated, which resulted in a total of 96,838 sequence reads from the LU_water samples and 119,907 from the LU_sediment samples (Table 1). For the publicly available metagenomes, the previously annotated sequence reads of 114,319 from AL_water, 80,924 from NB_water, 91,656 from MS_soil, and 95,228 from MDV_soil were used (Table 1).

\subsection{Taxonomic Distribution and Abundance}

At the domain level, gene sequences were mostly assigned to domain Bacteria (ranging from 93 to $98 \%$ ) in all Antarctic metagenomes (data not shown). Less than 1\% of the total gene sequences were assigned as Eukaryota and viruses in all Antarctic metagenomes used in this study, except for AL_water (1.9\% for eukaryotes; $3.8 \%$ for viruses). Archaea accounted for $2 \%$ in LU_water and NB_water; $1 \%$ in MS_soil and MDV_soil; and less than 1\% in LU_sediment and AL_water of the respective metagenome sequences. Additionally, $0.29 \%$ of the total sequence reads in the MS_soil sample did not match to any known taxa.

The relative abundances of microbial taxa at the phylum level showed that Proteobacteria was considerably abundant in all Antarctic metagenomes, ranging from 16.3 to $45.3 \%$ (Figure 2). In contrast, Bacteroidetes and Actinobacteria appeared to be the most abundant phylum in the NB_water (56.4\%) and MDV_soil (53.3\%) samples, respectively.

The microbial profiles in all Antarctic samples at the genus level showed diverse microbial taxa, with similarities but also significant differences, particularly between the water group (LU_water, AL_water, and NB_water) and the combined soil (MS_soil and MDV_soil) and lake sediment (LU_sediment) group (Figure 3). Overall, Myxococcus, Gloeobacter, Anaeromyxobacter, and Haliangium 
made a significant contribution to the combined soil and lake sediment metagenomes as compared to the water metagenomes. Conversely, Prochlorococcus and Thiomicrospira made a more significant contribution to the taxonomic profiles of the water metagenomes than the combined soil and lake sediment metagenomes.
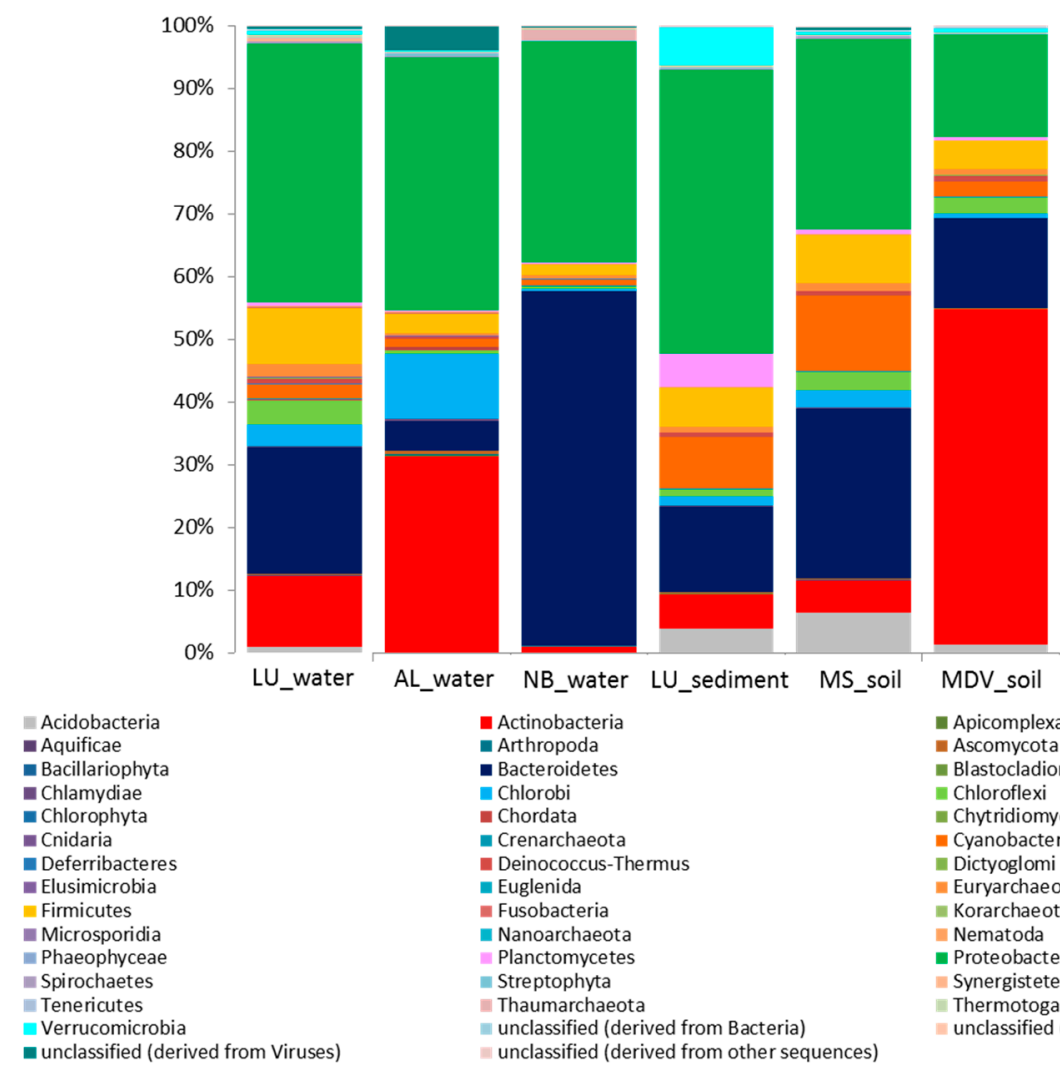

Actinobacteria
Arthropoda
Bacteroidetes
Chlorobi
Chordata
Crenarchaeota

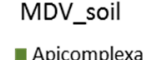

Apicomplexa

Blastocladiomycota

Inloroflexi

- Chytridiomycota

- Cyanobacteria

- Dictyoglomi

Euryarchaeota

Korarchaeota

Nematoda

Proteobacteri

- Synergistetes
- Thermotogae

unclassified (derived from Eukaryota)

Figure 2. Stacked column bar graph representing the microbial community composition at the phylum level across all samples used in this study. Taxonomic identities that could not be shown to the respective level of resolution were considered as "unclassified" within their corresponding domain. Relative abundance data was analyzed by using MG-RAST against the SEED database and then visualized using Microsoft Excel Software (Microsoft, Seattle, WA, USA). Sample names are included in the plot $\left(L U \_w a t e r=\right.$ Lake Untersee water; $A L \_w a t e r=$ Ace Lake water; NB_water $=$ Newcomb Bay Lake water; LU_sediment $=$ Lake Untersee sediment; MS_soil = Mount Seuss soil; MDV_soil = McMurdo Dry Valleys soil).

\subsection{Comparative Analyses of Functional Profiles}

The distribution and relative abundance of genes involved in CIPs and CASPs found in all metagenomes used in this study showed distinct clustering patterns among the samples (Figure 4). The MDS plots of the LU_water, LU_sediment, and MDV_soil samples were clustered together at $89 \%$ Bray-Curtis similarity (Figure 4A). All samples, except MS_soil, grouped together at 84\% Bray-Curtis similarity. The MS_soil sample showed relatively higher intra-sample variability, although it did cluster together with all other samples at 75\% Bray-Curtis similarity. These clustering patterns were supported by the complete linkage hierarchical clustering dendrogram analysis (Figure 4B,C). Within the three water samples, LU_water revealed a slight intra-group variability as compared to the other two water samples (AL_water and NB_water) (Figure 4B). Among the soil and lake sediment group, LU_sediment showed a high similarity with MDV_soil; however, these two samples were observed to be separated from the MS_soil. 

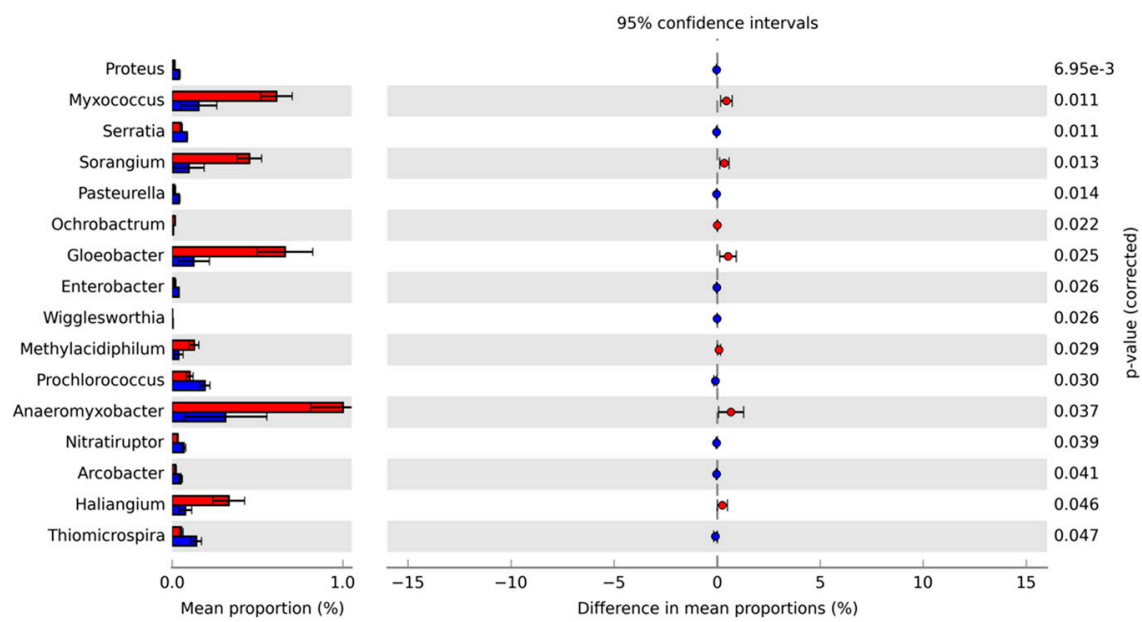

soil \& sediment $\square$ water

Figure 3. Extended error plot for taxonomic compositions at the genus level for Antarctic metagenomes used in this study was visualized through STAMP based on SEED subsystems. Total mean proportions in different categories are displayed in the left bar graph; the upper side (red) indicates the soil and lake sediment group (Lake Untersee sediment, Mount Seuss soil, and McMurdo Dry Valleys soil), and the lower side (blue) represents the water group (Lake Untersee water, Ace Lake water, Newcomb Bay Lake water). The colored circles (red and blue) show the $95 \%$ confidence intervals calculated using the Welch's $t$-test [50] with no correction and default parameters.

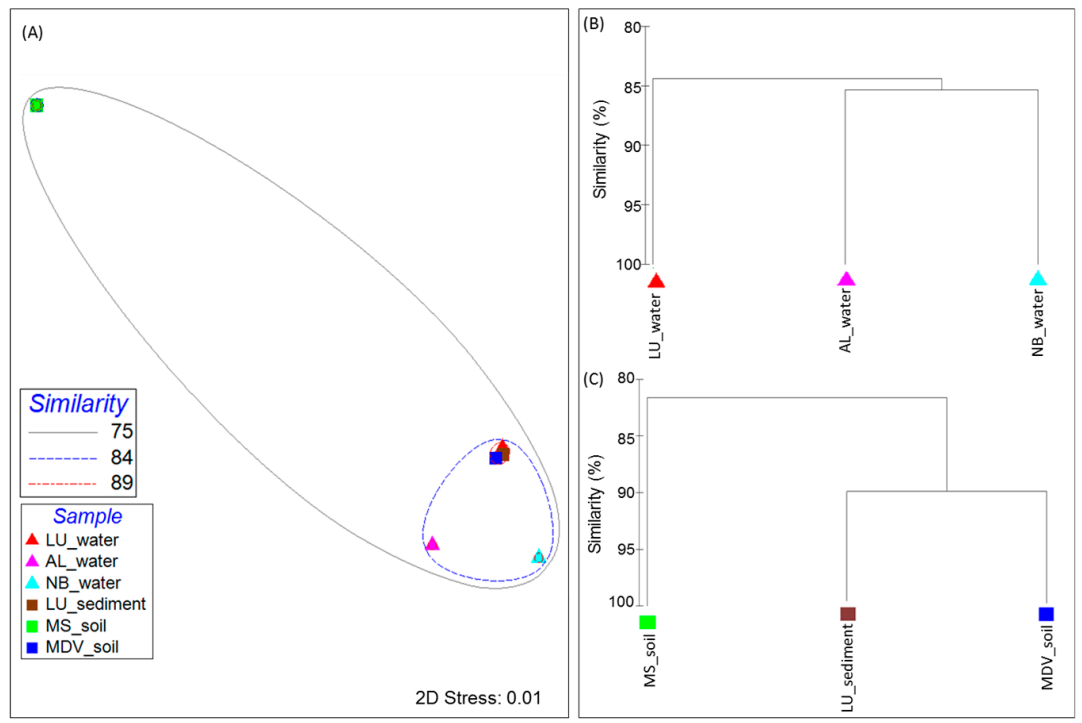

Figure 4. Beta diversity visualization of the filtered cold-induced and cold-associated general stress-responsive proteins across all samples used in this study. (A) Multidimensional-scaling (MDS) plot analysis representing the cluster pattern in a two-dimensional (2D) rendering with similarity overlays. Samples are denoted as triangles and rectangles for the sample group type (corresponding to the water group and the soil and lake sediment group, respectively) in the plot, and are colored by the sample. The dendrogram displays the cluster patterns of (B) the water and (C) soil and lake sediment group samples according to the Bray-Curtis value as a percentage (0 to 100). Both plots were generated through PRIMER-6 Ecological Software based on the Bray-Curtis similarity metric. Sample names are included in the plot (LU_water = Lake Untersee water; AL_water = Ace Lake water; NB_water = Newcomb Bay Lake water; LU_sediment = Lake Untersee sediment; MS_soil = Mount Seuss soil; MDV_soil = McMurdo Dry Valleys soil). 


\subsection{Cold-Induced Proteins in the Water Metagenomes}

In the LU_water metagenome, all 26 CIPs were detected, showing a high number of genes ( $>100$ sequences) associated with chaperone protein DnaK, DNA gyrase subunit A (GyrA), and general recombination and DNA repair protein (RecA) (Figure 5A and Table 2). Interestingly, as compared to the AL_water and NB_water samples, the CspB and H-NS proteins were only found in LU_water samples.

In the AL_water metagenome, a total of $24 \mathrm{CIPs}$ were found, showing a relatively high abundance of genes (>100 sequences) related to pyruvate dehydrogenase E1 component (AceE), chaperone proteins (DnaK and DnaJ), translation initiation factor 2 (IF2), GyrA, chromosomal replication initiator protein (DnaA), and RecA (Figure 5A and Table 2). As compared to LU_water and the NB_water, AL_water showed $>2.5$ times higher sequence reads for the pyruvate dehydrogenase E1 component protein (AceE).

In the NB_water metagenome, a total of 21 CIPs were found, showing a high number of genes ( $>100$ sequences) related to IF2, DnaK, GyrA, RecA, transcription termination protein (NusA), DnaA, and DnaJ (Figure 5A and Table 2). Interestingly, purine nucleoside phosphorylase (PNP) and cold-shock DEAD-box protein A (CSDA) were found to be $>1.5$ times higher in the NB_water as compared to the AL_water and LU_water metagenomes.

Overall, gene sequences associated with GyrA, RecA, DnaA, DnaJ, DnaK, IF2, and NusA were found to be predominant in all three water metagenomes.

(A)

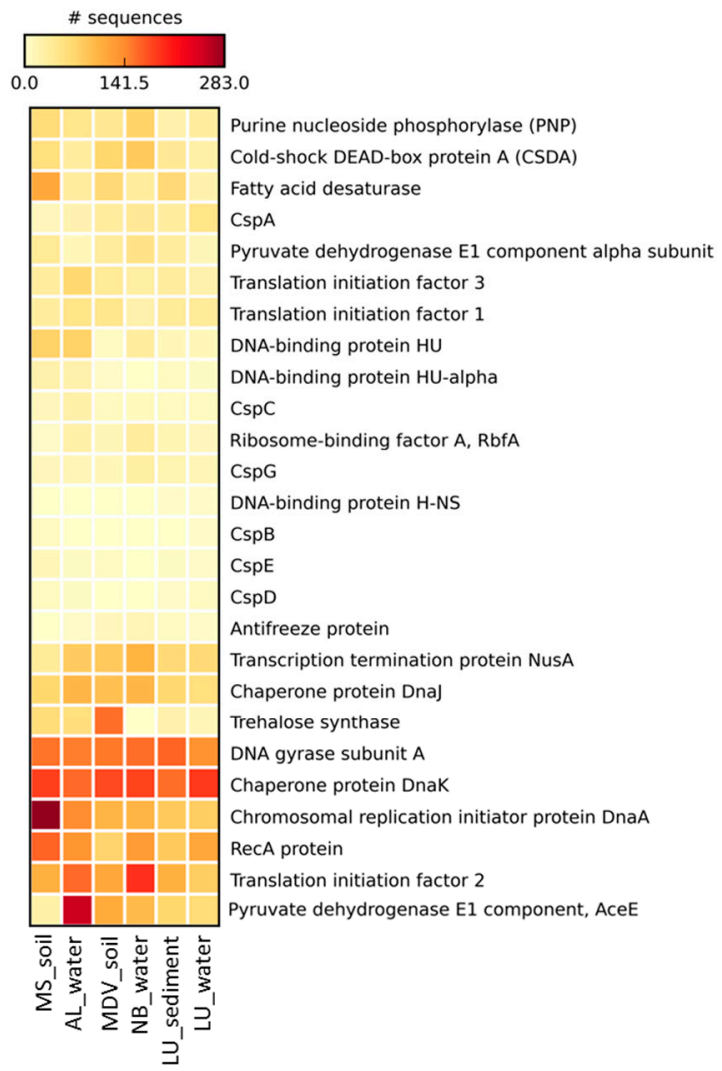

(B)
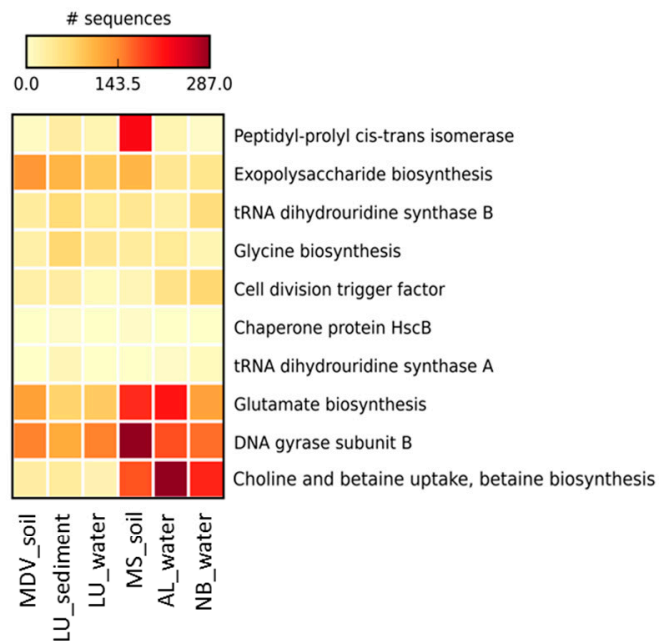

Figure 5. Heatmap representing the relative abundance of the (A) cold-induced proteins and (B) cold-associated general stress-responsive proteins found in this study against the SEED database. The heatmap was generated through STAMP [51] with the average neighbor (UPGMA) method using the default parameters. Larger values are represented in red and the smaller values in light yellow. Sample names are included in the plot (LU_water = Lake Untersee water; AL_water = Ace Lake water; NB_water = Newcomb Bay Lake water; LU_Sediment = Lake Untersee sediment; MS_soil = Mount Seuss soil; MDV_soil = McMurdo Dry Valleys soil). 
Table 2. Number of genes related to the cold-induced proteins and cold-associated general stress proteins found across all Antarctic metagenomes used in this study.

\begin{tabular}{|c|c|c|c|c|c|c|}
\hline \multirow[b]{2}{*}{ Protein or SEED subsystem name } & \multicolumn{6}{|c|}{ Number of Genes Found in Each Antarctic Metagenome } \\
\hline & $\begin{array}{l}\text { Lake } \\
\text { Untersee } \\
\text { water }\end{array}$ & $\begin{array}{l}\text { Ace } \\
\text { Lake } \\
\text { water }\end{array}$ & $\begin{array}{l}\text { Newcomb } \\
\text { Bay water }\end{array}$ & $\begin{array}{l}\text { Lake } \\
\text { Untersee } \\
\text { sediment }\end{array}$ & $\begin{array}{l}\text { Mount } \\
\text { Seuss soil }\end{array}$ & $\begin{array}{l}\text { McMurdo } \\
\text { Dry Valleys } \\
\text { soil }\end{array}$ \\
\hline \multicolumn{7}{|c|}{ Cold-Induced Proteins } \\
\hline \multicolumn{7}{|l|}{ Pyruvate metabolism } \\
\hline $\begin{array}{l}\text { Pyruvate dehydrogenase E1 component, } \\
\text { AceE }\end{array}$ & 65 & 255 & 96 & 70 & 26 & 111 \\
\hline $\begin{array}{l}\text { Pyruvate dehydrogenase E1 component } \\
\text { alpha subunit }\end{array}$ & 13 & 12 & 50 & 33 & 39 & 35 \\
\hline \multicolumn{7}{|l|}{ Cold stress proteins } \\
\hline CspA & 49 & 21 & 40 & 31 & 11 & 33 \\
\hline CspB & 2 & 0 & 0 & 1 & 8 & 0 \\
\hline CspC & 8 & 26 & 9 & 8 & 11 & 8 \\
\hline CspD & 7 & 4 & 0 & 3 & 8 & 1 \\
\hline CspE & 2 & 4 & 1 & 4 & 12 & 5 \\
\hline CspG & 15 & 15 & 29 & 18 & 11 & 12 \\
\hline Antifreeze protein & 3 & 3 & 15 & 6 & 1 & 10 \\
\hline \multicolumn{7}{|l|}{ Di- and oligosaccharides } \\
\hline Trehalose synthase & 14 & 58 & 0 & 24 & 62 & 156 \\
\hline \multicolumn{7}{|l|}{ Protein biosynthesis } \\
\hline Translation initiation factor 1 & 38 & 49 & 23 & 36 & 31 & 46 \\
\hline Translation initiation factor 2 & 80 & 160 & 193 & 106 & 108 & 114 \\
\hline Translation initiation factor 3 & 23 & 68 & 29 & 33 & 33 & 39 \\
\hline Ribosome-binding factor A, RbfA & 11 & 26 & 35 & 17 & 3 & 14 \\
\hline \multicolumn{7}{|l|}{ Clustering-based subsystems } \\
\hline Transcription termination protein NusA & 65 & 81 & 103 & 65 & 36 & 84 \\
\hline \multicolumn{7}{|l|}{ DNA metabolism } \\
\hline DNA-binding protein H-NS & 3 & 0 & 0 & 2 & 0 & 0 \\
\hline DNA-binding protein $\mathrm{HU}$ & 12 & 76 & 32 & 12 & 76 & 6 \\
\hline DNA-binding protein HU-alpha & 4 & 23 & 1 & 7 & 23 & 3 \\
\hline \multicolumn{7}{|l|}{ DNA replication } \\
\hline DNA gyrase subunit A & 133 & 149 & 158 & 163 & 155 & 152 \\
\hline RecA protein & 117 & 132 & 125 & 83 & 164 & 73 \\
\hline $\begin{array}{l}\text { Chromosomal replication initiator } \\
\text { protein DnaA }\end{array}$ & 80 & 139 & 102 & 84 & 283 & 102 \\
\hline \multicolumn{7}{|l|}{ Nucleosides and nucleotides } \\
\hline Purine nucleoside phosphorylase (PNP) & 33 & 47 & 75 & 24 & 63 & 42 \\
\hline \multicolumn{7}{|l|}{ Protein folding } \\
\hline Chaperone protein DnaJ & 58 & 100 & 100 & 69 & 70 & 91 \\
\hline Chaperone protein DnaK & 189 & 160 & 182 & 158 & 183 & 179 \\
\hline \multicolumn{7}{|l|}{ RNA metabolism } \\
\hline $\begin{array}{l}\text { Cold-shock DEAD-box protein A } \\
\text { (CSDA) }\end{array}$ & 27 & 31 & 84 & 40 & 58 & 70 \\
\hline \multicolumn{7}{|l|}{ Unsaturated fatty acids } \\
\hline Fatty acid desaturase & 22 & 33 & 34 & 66 & 114 & 65 \\
\hline
\end{tabular}


Table 2. Cont.

\begin{tabular}{|c|c|c|c|c|c|c|}
\hline \multirow[b]{2}{*}{ Protein or SEED subsystem name } & \multicolumn{6}{|c|}{ Number of Genes Found in Each Antarctic Metagenome } \\
\hline & $\begin{array}{l}\text { Lake } \\
\text { Untersee } \\
\text { water }\end{array}$ & $\begin{array}{c}\text { Ace } \\
\text { Lake } \\
\text { water }\end{array}$ & $\begin{array}{l}\text { Newcomb } \\
\text { Bay water }\end{array}$ & $\begin{array}{c}\text { Lake } \\
\text { Untersee } \\
\text { sediment }\end{array}$ & $\begin{array}{l}\text { Mount } \\
\text { Seuss soil }\end{array}$ & $\begin{array}{c}\text { McMurdo } \\
\text { Dry Valleys } \\
\text { soil }\end{array}$ \\
\hline \multicolumn{7}{|c|}{ Cold-Associated General Stress-Responsive Proteins } \\
\hline \multicolumn{7}{|l|}{ Amino acids and derivatives } \\
\hline Glycine biosynthesis & 42 & 40 & 16 & 69 & 34 & 28 \\
\hline Glutamate biosynthesis & 83 & 214 & 119 & 75 & 199 & 123 \\
\hline \multicolumn{7}{|l|}{ Bacterial cell division } \\
\hline Cell division trigger factor & 9 & 52 & 68 & 31 & 15 & 27 \\
\hline \multicolumn{7}{|l|}{ Osmotic stress } \\
\hline $\begin{array}{c}\text { Choline and betaine uptake, betaine } \\
\text { biosynthesis }\end{array}$ & 21 & 287 & 204 & 35 & 176 & 31 \\
\hline \multicolumn{7}{|l|}{$\begin{array}{l}\text { Cell wall and capsule (Capsular and } \\
\text { extracellular polysaccharides) }\end{array}$} \\
\hline Exopolysaccharide biosynthesis & 85 & 42 & 44 & 104 & 102 & 131 \\
\hline \multicolumn{7}{|l|}{ DNA replication } \\
\hline DNA gyrase subunit B & 150 & 178 & 160 & 115 & 286 & 149 \\
\hline \multicolumn{7}{|l|}{ Protein folding } \\
\hline Peptidyl-prolyl cis-trans isomerase & 18 & 18 & 3 & 31 & 224 & 5 \\
\hline \multicolumn{7}{|l|}{ RNA metabolism } \\
\hline Chaperone protein $\mathrm{HscB}$ & 1 & 0 & 1 & 3 & 2 & 0 \\
\hline tRNA dihydrouridine synthase A & 1 & 3 & 9 & 12 & 0 & 0 \\
\hline tRNA dihydrouridine synthase B & 40 & 28 & 60 & 63 & 43 & 32 \\
\hline
\end{tabular}

\subsection{Cold-Induced Proteins in the Combined Soil and Lake Sediment Metagenomes}

All 26 CIPs were found in the LU_sediment metagenome, revealing a high number of genes ( $>100$ sequences) associated with IF2, GyrA, and DnaK (Figure 5A and Table 2). Interestingly, H-NS was only found in LU_sediment as compared to the MS_soil and MDV_soil metagenomes.

A total of 25 CIPs were detected in the MS_soil metagenome, revealing a high number of genes (>100 sequences) associated with DnaA, DnaK, RecA, GyrA, fatty acid desaturase (FAD), and IF2 (Figure 5A and Table 2). Particularly, RecA, DnaA, PNP, FAD, and a DNA-binding protein (HU) were considerably higher in the MS_soil as compared to the LU_sediment and the MDV_soil metagenomes.

In the MDV_soil metagenomes, a total 24 CIPs were found, among which DnaK, trehalose synthase (TS), GyrA, IF2, AceE, and DnaA were highly abundant (>100 sequences) (Figure 5A and Table 2). As compared to the LU_sediment and MS_soil metagenomes, TS and AceE were substantially abundant in MDV_soil.

In general, gene sequences for the DnaK, GyrA, IF2, RecA, DnaA, and FAD proteins were highly abundant in the combined soil and lake sediment metagenomes.

\subsection{Cold-Associated General Stress-Responsive Proteins in the Water Metagenomes}

All 10 CASPs were found in the LU-water metagenome, showing DNA gyrase subunit B (GyrB) as the most abundant (>100 sequences), followed by exopolysaccharide (EPS) biosynthesis (85 sequences) and glutamate biosynthesis (83 reads) (Figure 5B and Table 2). Especially, EPS biosynthesis was more abundant ( 2 times more) in the LU_water than the AL_water and the NB_water metagenomes.

A total of 9 CASPs were found in the AL_water metagenome, showing choline and betaine uptake and biosynthesis and glutamate biosynthesis as the most highly abundant CASPs ( $>200$ sequences) followed by GyrB (178 sequences) (Figure 5B and Table 2). Additionally, choline and betaine uptake 
and biosynthesis and glutamate biosynthesis sequences were found to be the most abundant in the AL_water metagenome among all water metagenomes used in this study.

A total of 10 CASPs were detected in the NB_water metagenome. Choline and betaine uptake and biosynthesis were the most abundant CASPs in the NB_water metagenome followed by GyrB (160 reads) and glutamate biosynthesis (119 reads) (Figure 5B and Table 2). A relatively higher ( $>1.5$ times more) abundance of both tRNA dihydrouridine synthase $\mathrm{A}$ and $\mathrm{B}$ was found in the NB_water metagenome compared with the AL_water and LU_water metagenomes.

In general, as compared to the LU_water metagenome, the distribution of CASPs, particularly the gene sequences for glutamate biosynthesis (214 and 119 reads, respectively) and choline and betaine uptake and biosynthesis (287 and 204 reads, respectively), was highly abundant in the AL_water and NB_water metagenomes. GyrB was highly abundant across all water metagenomes.

\subsection{Cold-Associated General Stress-Responsive Proteins in the Combined Soil and Lake Sediment Metagenomes}

In the LU_sediment metagenome, a total of 10 CASPs were found, revealing GyrB and EPS biosynthesis as the most abundant CASPs ( $>100$ sequences) (Figure $5 \mathrm{~B}$ and Table 2 ). Genes related to both tRNA dihydrouridine synthase A and B were relatively higher (75 total reads) in the LU_sediment metagenome than in the MS_soil (43 reads) and MDV_soil (32 reads) soil metagenomes.

A total of 9 CASPs were found in the MS_soil metagenome, in which GyrB sequences were found to be the most abundant ( $>200$ sequences) followed by peptidyl-prolyl cis-trans isomerase, glutamate biosynthesis, choline and betaine uptake and biosynthesis, and EPS biosynthesis (Figure 5B and Table 2). All of these sequences were also substantially abundant in the LU_sediment and MDV_soil metagenomes.

In the MDV_soil metagenome, a total of 8 CASPs were identified, in which GyrB was the most abundant (>200 sequences) followed by EPS biosynthesis (131 reads) and glutamate biosynthesis (123 reads) (Figure 5B and Table 2). Interestingly, chaperone protein $\mathrm{HscB}$ and tRNA dihydrouridine synthase A were absent in the MDV_soil metagenome when compared to the LU_sediment metagenome.

Overall, glutamate biosynthesis, GyrB, and EPS biosynthesis were the highly abundant CASPs across all combined soil and lake sediment metagenomes.

\section{Discussion}

The rapid advancements of culture-independent NGS have revolutionized our understanding of the microbial communities and their functional genes in a wide range of ecosystems, including the polar environments [58-60]. By using this approach, the bacterial metabolic genes for adaptation to cold temperature environments have been studied in cyanobacterial mats in Arctic and Antarctic ice shelves [21], microbial mats from Antarctic Lake Joyce [18], and permafrost samples from Alaska [61]. In order to obtain collective insights into the microbial distributions and abundances of genes associated with CIPs and CASPs, we have analyzed metagenomes from Lake Untersee water and sediment samples for comparison with selected publicly available soils and water metagenomes from diverse ecosystems in the Antarctic continent.

In general, the microbiota of all metagenomes used in this study showed mostly comparable taxonomic compositions. For example, Proteobacteria and Bacteroidetes were the abundant phyla, whereas phylum Actinobacteria, although varied in their abundances, were found in all metagenomes. The microbial taxa and cold-adaptive traits found in our samples have also been reported previously in diverse Antarctic soil, sediment, and aquatic ecosystems [21,62-65]. Despite the similarities in microbial composition across all metagenomes, noticeable differences at the genus level were found when compared between the water and the combined soil and lake sediment metagenomes. The water metagenomes had relatively higher abundances of Prochlorococcus and Thiomicrospira than the soil and lake sediment metagenomes, which was also reported in several sub-zero Antarctic lakes [15]. Prochlorococcus and Thiomicrospira are known to be one of the key contributors to Antarctic aquatic ecosystems as they are characterized as photosynthetic organisms and autotrophic sulfur-oxidizing 
gammaproteobacterium, respectively [15]. In contrast, the soil and lake sediment metagenomes showed relatively higher abundances of Myxococcus, Anaeromyxobacter, and Haliangium than the water metagenomes. Myxococcus, Anaeromyxobacter, and Haliangium have been previously found in other Antarctic soil samples [66]; and Gloeobacter has been reported in Antarctic sediment samples [67]. Interestingly, myxobacteria (such as Myxococcus) have been generally considered to be mesophilic soil microbes [68]; however, the first psychrophilic myxobacteria were identified in soil samples in Antarctic McMurdo Dry Valleys and South Victoria Land [68]. A few other studies have also reported Anaeromyxobacter, Haliangium, and Gloeobacter in Antarctic soil and sediment ecosystems.

The cold-adaptive traits in water metagenomes revealed a generally similar distribution of CIPs, including a high number of genes associated with DNA replication (GyrA, RecA, and DnaA), protein folding (chaperone proteins DnaJ and DnaK), protein biosynthesis (translation initiation factor), and the transcription termination protein NusA. Like the water metagenomes, the soil and lake sediment metagenomes also showed similar CIP distributions in all samples. Within the cold stress proteins (cold shock family of proteins), CspA was found to be highly abundant in each water and combined soil and lake sediment metagenome. At low temperatures, cold stress proteins are expressed quickly and remain active to stabilize the mRNA, thus helping proper protein folding and allowing bacteria to adapt their physiology to the cold temperature environments $[17,18,21,69,70]$. Particularly, CspA is known to function as an RNA chaperone, destabilizing the secondary structures of mRNA necessary for the expression of the cold-inducible proteins and enhancing the expression of GyrA [18,71,72]. Moreover, CspA, CspC, and CspE act as transcriptional anti-terminators, allowing alternative mechanisms for the regulation of other CIPs, such as NusA, IF2, RbfA, and PNPase [73]. Although each water and combined soil and lake sediment metagenome showed a lower abundance of cold-responsive stress proteins as compared to DnaA, DnaK, DnaJ, DNA topoisomerases, and recombination factors, these proteins have been observed to be highly abundant, particularly in Antarctic and Arctic ecosystems. This is due to their role in helping bacteria maintain steady-state cellular metabolism, growth, and division in order to cope with the consistent cold environments [18,21].

In the presence of cold stress, bacterial cell membranes undergo decreased membrane fluidity but an increase in permeability. It has been reported that FAD offsets membrane stiffness by modifying the existing fatty acid chain structures of the cell membrane [74-77]. Moreover, TS has been characterized to be involved in numerous stress-related processes and predicted to function in the restriction of oxidative damage, cryopreservation, and cell membrane protection [78-81]. The combined soil and lake sediment metagenomes showed more genes related to FAD and TS than the water metagenomes. Especially, FAD and TS were more abundant in the MS_soil and the MDV_soil metagenomes, implying that protective responses are needed for bacteria surviving in the open soil ecosystems due to the fluctuations in temperatures, desiccation, and poor nutrient availability. H-NS is known as a nucleoid-associated DNA binding protein [82] and a regulator of the expression of various cold shock genes [83-86]. In our study, H-NS was only found in the LU_water and the LU_sediment metagenomes. This may support the presence of almost the entire cold-shock family of proteins (CspA, $\mathrm{CspB}, \mathrm{CspC}, \mathrm{CspD}, \mathrm{CspE}, \mathrm{CspG}$, and antifreeze proteins) in the metagenomes of Lake Untersee.

The distribution of CASPs in each water and combined soil and lake sediment metagenome showed genes associated with the regulation of GyrB (DNA gyrase) and glutamate biosynthesis. DNA gyrase is known to play an important role in regulating DNA topology during transcription and manifests higher activity at cold temperatures $[73,77,87]$. Glutamate, glycine, choline, and betaine are known cryo- and osmoprotectants [21,88], thus supporting our results of heightened glutamate synthesis genes observed in all metagenomes. Furthermore, choline and betaine biosynthesis allow bacteria to increase osmolality, thus helping to protect against cold-related damage to the cell structure and function [89]. A high representation of glutamate biosynthesis in all metagenomes used in this study might reflect the high osmotic stress present across the Antarctic continent. Additionally, the high number of genes associated with choline and betaine biosynthesis found in the AL_water and NB_water metagenomes as opposed to the LU_water metagenome may be due to the relatively higher 
salt concentrations in the Ace and Newcomb Bay lakes as compared to the freshwater of Lake Untersee. EPS also plays an important role in cryoprotection against ice crystal damage and high salinity [19,21]. A relatively higher abundance of genes associated with EPS biosynthesis was found in Lake Untersee and the combined soil and lake sediment metagenomes than in Ace Lake and Newcomb Bay Lake metagenomes. This may be due to a relatively higher abundance of Cyanobacteria, which are known to produce a copious amount of EPS [21]. All water and combined soil and lake sediment metagenomes had a noteworthy distribution of tRNA dihydrouridine synthase, which is known to help maintain conformational flexibility and dynamic motion of tRNA at cold temperatures [90]. Thus, an abundance of sequences for tRNA dihydrouridine synthase in our metagenomes indicates an adaptive advantage in microorganisms inhabiting the Antarctic environment.

In a previous study, the shotgun metagenomics approach was applied to the microbial communities of a laboratory culture of Euplotes focardii, a psychrophilic marine ciliate collected from sediments in Terra Nova Bay, Antarctica [91]. These microbial communities were considered to be representative of the Antarctic sample upon collection, and, similar to this study, showed a heightened distribution of the phyla Proteobacteria followed by Bacteroidetes. Functional analysis demonstrated ice binding and antifreeze proteins and proteins involved in the oxidative stress response, which supported the postulated underlying genetic capacity for adaptation to their consistently cold and oxygen-rich environment. Interestingly, antibiotic treatment of the ciliate cultures showed a reduction in the proliferation of E. focardii, which was attributed to the loss of key biogeochemical (carbon and nitrogen) and nutrient cycling performed by the associated microbiota. As such, the various cold-responsive stress genes (CIPs and CASPs) observed in the extreme Antarctic ecosystems of this study demonstrate crucial microbial adaptations to cold stress, allowing for both their persistence and possible sustenance of other inhabiting organisms that are metabolically restricted by the cold stress.

The mechanisms of bacterial genetic adaptation in low- and subzero-temperature environments have been well-reported [63,69]. Our analyses included the updated list of CIPs and CASPs found in microbial metagenomes. These proteins have been filtered from the metagenomics datasets by using bioinformatics tools to achieve a comprehensive outlook of microbial community composition and mechanisms to cope with cold and other stresses present in Antarctica. Overall, noticeable differences were found in the microbial taxa distribution and various cold- and stress-related functions among all Antarctic metagenomes. However, the key genes necessary for adaptation in the continuous low- and subzero-temperature environment were well-represented across all Antarctic metagenomes used in this study. Moreover, the permanently ice-covered Lake Untersee metagenomes had high abundances of sequences for cold-responsive stress proteins and H-NS, indicating that this lake environment poses comparatively greater survival challenges to the inhabiting microbial communities.

Author Contributions: H.K and A.K.B. conceived the study. D.T.A. collected water and sediment samples from Lake Untersee, Antarctica. H.K. conducted the experiments and analyzed the NGS data. H.K., J.A.H. and A.K.B. wrote the manuscript; and C.D.M., M.R.C. conducted the metagenome sequencing; C.D.M., M.R.C. and D.T.A. contributed and commented in the preparation of the manuscript. A.K.B. oversaw the overall progress of this study.

Funding: Primary support for this research was provided by the TAWANI Foundation, the Trottier Family Foundation, and the Arctic and Antarctic Research Institute/Russian Antarctic Expedition. The following are acknowledged for their support of the Microbiome Resource at the University of Alabama at Birmingham: the Comprehensive Cancer Center (P30AR050948), the Center for Clinical and Translational Science (UL1TR001417), and the University Wide Institutional Core and Heflin Center for Genomic Sciences.

Acknowledgments: Antarctic logistics support was provided by the Antarctic Logistics Centre International (ALCI), Cape Town, South Africa. We also thank Matthew Pace, Mathew Thompson, and T.D. Todd of CAS IT for computer support and Peter Eipers of the Department of Cell, Developmental, and Integrative Biology at the UAB for assistance in the Next Generation Sequencing for this study.

Conflicts of Interest: The authors declare no conflict of interest associated with this study; the study was conducted solely for the purpose of a scientific study. 


\section{References}

1. Knoll, A.H. Life on a Young Planet: The First Three Billion Years of Evolution on Earth; Princeton University Press: Princeton, NJ, USA, 2015; ISBN 9780691165530.

2. Whitman, W.B.; Coleman, D.C.; Wiebe, W.J. Prokaryotes: The unseen majority. Proc. Nat. Acad. Sci. USA 1998, 95, 6578-6583. [CrossRef] [PubMed]

3. Rothschild, L.J.; Mancinelli, R.L. Life in extreme environments. Nature 2001, 409, 1092. [CrossRef] [PubMed]

4. Rampelotto, P.H. Extremophiles and extreme environments. Life 2013, 3, 482-485. [CrossRef] [PubMed]

5. Häggblom, M.; Margesin, R. Microbial life in cold ecosystems. FEMS Microbiol. Ecol. 2005, 53, 1-2. [CrossRef]

6. Laybourn-Parry, J. No place too cold. Science 2009, 324, 1521-1522. [CrossRef] [PubMed]

7. Onofri, S.; Selbmann, L.; De Hoog, G.; Grube, M.; Barreca, D.; Ruisi, S.; Zucconi, L. Evolution and adaptation of fungi at boundaries of life. Adv. Space Res. 2007, 40, 1657-1664. [CrossRef]

8. Horowitz, N.; Cameron, R.E.; Hubbard, J.S. Microbiology of the dry valleys of Antarctica. Science 1972, 176, 242-245. [CrossRef] [PubMed]

9. Cowan, D.A. Cryptic microbial communities in Antarctic deserts. Proc. Natl. Acad. Sci. USA 2009, 106, 19749-19750. [CrossRef] [PubMed]

10. Ji, M.; Greening, C.; Vanwonterghem, I.; Carere, C.R.; Bay, S.K.; Steen, J.A.; Montgomery, K.; Lines, T.; Beardall, J.; van Dorst, J. Atmospheric trace gases support primary production in Antarctic desert surface soil. Nature 2017, 552, 400-403. [CrossRef] [PubMed]

11. Lopatina, A.; Medvedeva, S.; Shmakov, S.; Logacheva, M.D.; Krylenkov, V.; Severinov, K. Metagenomic analysis of bacterial communities of Antarctic surface snow. Front. Microbiol. 2016, 7, 398. [CrossRef] [PubMed]

12. Molina-Montenegro, M.A.; Ballesteros, G.I.; Castro-Nallar, E.; Meneses, C.; Torres-Díaz, C.; Gallardo-Cerda, J. Metagenomic exploration of soils microbial communities associated to Antarctic vascular plants. PeerJ Preprints 2018, 6, e26508v1. [CrossRef]

13. Sommers, P.; Darcy, J.L.; Gendron, E.M.; Stanish, L.F.; Bagshaw, E.A.; Porazinska, D.L.; Schmidt, S.K. Diversity patterns of microbial eukaryotes mirror those of bacteria in Antarctic cryoconite holes. FEMS Microbiol. Ecol. 2017, 94, fix167. [CrossRef] [PubMed]

14. Tytgat, B.; Verleyen, E.; Obbels, D.; Peeters, K.; De Wever, A.; D’hondt, S.; De Meyer, T.; Van Criekinge, W.; Vyverman, W.; Willems, A. Bacterial diversity assessment in Antarctic terrestrial and aquatic microbial mats: A comparison between bidirectional pyrosequencing and cultivation. PLoS ONE 2014, 9, e97564. [CrossRef] [PubMed]

15. Wilkins, D.; Yau, S.; Williams, T.J.; Allen, M.A.; Brown, M.V.; DeMaere, M.Z.; Lauro, F.M.; Cavicchioli, R. Key microbial drivers in antarctic aquatic environments. FEMS Microbiol. Rev. 2013, 37, 303-335. [CrossRef] [PubMed]

16. Casanueva, A.; Tuffin, M.; Cary, C.; Cowan, D.A. Molecular adaptations to psychrophily: The impact of 'omic'technologies. Trends Microbiol. 2010, 18, 374-381. [CrossRef] [PubMed]

17. Koo, H.; Hakim, J.A.; Bej, A.K. Metagenomic analysis of microbial cold stress proteins in polar lacustrine ecosystems. In Stress and Environmental Regulation of Gene Expression and Adaptation in Bacteria; De Bruijn, F., Ed.; John Wiley \& Sons, Inc.: Hoboken, NJ, USA, 2016; Volume 2, pp. 837-844. ISBN 9781119004813.

18. Koo, H.; Hakim, J.A.; Fisher, P.R.; Grueneberg, A.; Andersen, D.T.; Bej, A.K. Distribution of cold adaptation proteins in microbial mats in Lake Joyce, Antarctica: Analysis of metagenomic data by using two bioinformatics tools. J. Microbiol. Methods 2016, 120, 23-28. [CrossRef] [PubMed]

19. Tribelli, P.M.; López, N.I. Reporting key features in cold-adapted bacteria. Life 2018, 8, 8. [CrossRef] [PubMed]

20. Yau, S.; Cavicchioli, R. Microbial communities in Antarctic lakes: Entirely new perspectives from metagenomics and metaproteomics. Microbiol. Aust. 2011, 32, 157-159.

21. Varin, T.; Lovejoy, C.; Jungblut, A.D.; Vincent, W.F.; Corbeil, J. Metagenomic analysis of stress genes in microbial mat communities from Antarctica and the High Arctic. Appl. Environ. Microbiol. 2012, 78, 549-559. [CrossRef] [PubMed]

22. Priscu, J.C.; Wolf, C.F.; Takacs, C.D.; Fritsen, C.H.; Laybourn-Parry, J.; Roberts, E.C.; Sattler, B.; Lyons, W.B. Carbon transformations in a perennially ice-covered Antarctic lake. Bioscience 1999, 49, 997-1008. [CrossRef]

23. Laybourn-Parry, J.; Wadham, J.L. Antarctic Lakes; Oxford University Press: Oxford, UK, 2014; ISBN 9780199670505. 
24. Bowman, J.S.; Vick-Majors, T.J.; Morgan-Kiss, R.; Takacs-Vesbach, C.; Ducklow, H.W.; Priscu, J.C. Microbial community dynamics in two polar extremes: The lakes of the McMurdo Dry Valleys and the West Antarctic Peninsula marine ecosystem. Bioscience 2016, 66, 829-847. [CrossRef]

25. Andersen, D.; Doran, P.; Bolshiyanov, D.; Rice, J.; Galchenko, V.; Cherych, N.; Wharton, R.; McKay, C.; Meyer, M.; Garshnek, V. A preliminary comparison of two perennially ice-covered lakes in Antarctica: Analogs of past martian lacustrine environments. Adv. Space Res. 1995, 15, 199-202. [CrossRef]

26. Wharton, R.A.; Simmons, G.M.; McKay, C.P. Perennially ice-covered Lake Hoare, Antarctica: Physical environment, biology and sedimentation. Hydrobiologia 1989, 172, 305-320. [CrossRef] [PubMed]

27. Spigel, R.H.; Priscu, J.C. Physical Limnology of the McMurdo Dry Valleys Lakes. In Ecosystem Dynamics in a Polar Desert: The McMurdo Dry Valleys, Antarctica; Priscu, J.C., Ed.; American Geophysical Union: Washington, DC, USA, 1998; Volume 72, pp. 157-187. ISBN 9780875908991.

28. Kwon, M.; Kim, M.; Takacs-Vesbach, C.; Lee, J.; Hong, S.G.; Kim, S.J.; Priscu, J.C.; Kim, O.S. Niche specialization of bacteria in permanently ice-covered lakes of the McMurdo Dry Valleys, Antarctica. Environ. Microbiol. 2017, 19, 2258-2271. [CrossRef] [PubMed]

29. Steel, H.; McKay, C.; Andersen, D. Modeling circulation and seasonal fluctuations in perennially ice-covered and ice-walled Lake Untersee, Antarctica. Limnol. Oceanogr. 2015, 60, 1139-1155. [CrossRef]

30. Andersen, D.; Sumner, D.; Hawes, I.; Webster-Brown, J.; McKay, C. Discovery of large conical stromatolites in Lake Untersee, Antarctica. Geobiology 2011, 9, 280-293. [CrossRef] [PubMed]

31. Wand, U.; Schwarz, G.; Brüggemann, E.; Bräuer, K. Evidence for physical and chemical stratification in Lake Untersee (central Dronning Maud Land, East Antarctica). Antarct. Sci. 1997, 9, 43-45. [CrossRef]

32. Wand, U.; Perlt, J. Glacial boulders 'floating' on the ice cover of Lake Untersee, East Antarctica. Antarct. Sci. 1999, 11, 256-260. [CrossRef]

33. Wand, U.; Samarkin, V.A.; Nitzsche, H.-M.; Hubberten, H.-W. Biogeochemistry of methane in the permanently ice-covered Lake Untersee, central Dronning Maud Land, East Antarctica. Limnol. Oceanogr. 2006, 51, 1180-1194. [CrossRef]

34. Andersen, D. Antarctic Inland Waters: Scientific Diving in the Perennially Ice-Covered Lakes of the McMurdo Dry Valleys and Bunger Hills. In Proceedings of the International Polar Diving Workshop, Svalbard, 2007; Lang, M.A., Sayer, M.D.J., Eds.; Smithsonian Institution: Washington, DC, USA, 2007; pp. 163-170.

35. Glass, E.M.; Wilkening, J.; Wilke, A.; Antonopoulos, D.; Meyer, F. Using the Metagenomics RAST server (MG-RAST) for analyzing shotgun metagenomes. Cold Spring Harbor Protoc. 2010, 2010. [CrossRef] [PubMed]

36. Meyer, F.; Paarmann, D.; D’Souza, M.; Olson, R.; Glass, E.M.; Kubal, M.; Paczian, T.; Rodriguez, A.; Stevens, R.; Wilke, A. The metagenomics RAST server-A public resource for the automatic phylogenetic and functional analysis of metagenomes. BMC Bioinform. 2008, 9, 386. [CrossRef] [PubMed]

37. Koo, H.; Mojib, N.; Hakim, J.A.; Hawes, I.; Tanabe, Y.; Andersen, D.T.; Bej, A.K. Microbial communities and their predicted metabolic functions in growth laminae of a unique large conical mat from Lake Untersee, East Antarctica. Front. Microbiol. 2017, 8, 1347. [CrossRef] [PubMed]

38. Jungblut, A.D.; Hawes, I. Using Captain Scott's discovery specimens to unlock the past: Has Antarctic cyanobacterial diversity changed over the last 100 years? Proc. R. Soc. B 2017, 284, 20170833. [CrossRef] [PubMed]

39. Ausubel, F.M.; Brent, R.; Kingston, R.E.; Moore, D.D.; Smith, J.G.; Sideman, J.G.; Struhl, K. Current Protocols in Molecular Biology; John Wiley \& Sons: Media, PA, USA, 1987.

40. Ng, C.; DeMaere, M.Z.; Williams, T.J.; Lauro, F.M.; Raftery, M.; Gibson, J.A.; Andrews-Pfannkoch, C.; Lewis, M.; Hoffman, J.M.; Thomas, T. Metaproteogenomic analysis of a dominant green sulfur bacterium from Ace Lake, Antarctica. ISME J. 2010, 4, 1002-1019. [CrossRef] [PubMed]

41. Lauro, F.M.; DeMaere, M.Z.; Yau, S.; Brown, M.V.; Ng, C.; Wilkins, D.; Raftery, M.J.; Gibson, J.A.; Andrews-Pfannkoch, C.; Lewis, M. An integrative study of a meromictic lake ecosystem in Antarctica. ISME J. 2011, 5, 879-895. [CrossRef] [PubMed]

42. Williams, T.J.; Wilkins, D.; Long, E.; Evans, F.; DeMaere, M.Z.; Raftery, M.J.; Cavicchioli, R. The role of planktonic Flavobacteria in processing algal organic matter in coastal East Antarctica revealed using metagenomics and metaproteomics. Environ. Microbiol. 2013, 15, 1302-1317. [CrossRef] [PubMed]

43. Van Goethem, M.W.; Pierneef, R.; Bezuidt, O.K.; Van De Peer, Y.; Cowan, D.A.; Makhalanyane, T.P. A reservoir of 'historical' antibiotic resistance genes in remote pristine Antarctic soils. Microbiome 2018, 6, 40. [CrossRef] [PubMed] 
44. Fierer, N.; Leff, J.W.; Adams, B.J.; Nielsen, U.N.; Bates, S.T.; Lauber, C.L.; Owens, S.; Gilbert, J.A.; Wall, D.H.; Caporaso, J.G. Cross-biome metagenomic analyses of soil microbial communities and their functional attributes. Proc. Natl. Acad. Sci. USA 2012, 109, 21390-21395. [CrossRef] [PubMed]

45. Joshi, N.; Fass, J. Sickle: A Sliding-Window, Adaptive, Quality-Based Trimming Tool for Fastq Files, Version 1.33, Software. 2011. Available online: https:/ / github.com/najoshi/sickle (accessed on 10 July 2018).

46. Andrews, S. Fastqc: A Quality Control Tool for High Throughput Sequence Data, Version 0.11.7, Software. 2010. Available online: http:/ / www.bioinformatics.babraham.ac.uk/projects/fastqc/ (accessed on 10 July 2018).

47. Peng, Y.; Leung, H.C.; Yiu, S.-M.; Chin, F.Y. IDBA-UD: A de novo assembler for single-cell and metagenomic sequencing data with highly uneven depth. Bioinformatics 2012, 28, 1420-1428. [CrossRef] [PubMed]

48. Gurevich, A.; Saveliev, V.; Vyahhi, N.; Tesler, G. Quast: Quality assessment tool for genome assemblies. Bioinformatics 2013, 29, 1072-1075. [CrossRef] [PubMed]

49. Overbeek, R.; Begley, T.; Butler, R.M.; Choudhuri, J.V.; Chuang, H.-Y.; Cohoon, M.; de Crécy-Lagard, V.; Diaz, N.; Disz, T.; Edwards, R. The subsystems approach to genome annotation and its use in the project to annotate 1000 genomes. Nucleic Acids Res. 2005, 33, 5691-5702. [CrossRef] [PubMed]

50. Bluman, A.G. Elementary Statistics: A Step by Step Approach, 6th ed.; McGraw-Hill Higher Education: New York, NY, USA, 2007; ISBN 9780073271606.

51. Parks, D.H.; Tyson, G.W.; Hugenholtz, P.; Beiko, R.G. Stamp: Statistical analysis of taxonomic and functional profiles. Bioinformatics 2014, 30, 3123-3124. [CrossRef] [PubMed]

52. Clarke, K.R. Non-parametric multivariate analyses of changes in community structure. Aust. J. Ecol. 1993, 18, 117-143. [CrossRef]

53. Clarke, K.R.; Gorley, R.N. Primer v5 (Plymouth Routines in Multivariate Ecological Research): User Manual/Tutorial; Primer-E: Plymouth, UK, 2001.

54. Kruskal, J.; Wish, M. Quantitative Applications in the Social Sciences: Multidimensional Scaling; Sage: Beverly Hills, CA, USA, 1978; Volume 11, ISBN 9780803909403.

55. Dawyndt, P.; De Meyer, H.; De Baets, B. The complete linkage clustering algorithm revisited. Soft Comput. 2005, 9, 385-392. [CrossRef]

56. Krebs, C.J. Ecological Methodology; Benjamin/Cummings: Menlo Park, CA, USA, 1999; Volume 620, ISBN 9780321021731.

57. Bray, J.R.; Curtis, J.T. An ordination of the upland forest communities of southern Wisconsin. Ecol. Monogr. 1957, 27, 325-349. [CrossRef]

58. White, R.A., III; Callister, S.J.; Moore, R.J.; Baker, E.S.; Jansson, J.K. The past, present and future of microbiome analyses. Nat. Protoc. 2016, 11, 2049. [CrossRef]

59. Sjöling, S.; Cowan, D.A. Metagenomics: Microbial community genomes revealed. In Psychrophiles: From Biodiversity to Biotechnology; Margesin, R., Schinner, F., Marx, J.C., Gerday, C., Eds.; Springer: Berlin/Heidelberg, Germany, 2008; pp. 313-332. ISBN 9783540743347.

60. Fuks, G.; Elgart, M.; Amir, A.; Zeisel, A.; Turnbaugh, P.J.; Soen, Y.; Shental, N. Combining 16S rRNA gene variable regions enables high-resolution microbial community profiling. Microbiome 2018, 6, 17. [CrossRef] [PubMed]

61. Mackelprang, R.; Burkert, A.; Haw, M.; Mahendrarajah, T.; Conaway, C.H.; Douglas, T.A.; Waldrop, M.P. Microbial survival strategies in ancient permafrost: Insights from metagenomics. ISME J. 2017, 11, 2305. [CrossRef] [PubMed]

62. Nichols, C.M.; Bowman, J.P.; Guezennec, J. Effects of incubation temperature on growth and production of exopolysaccharides by an Antarctic sea ice bacterium grown in batch culture. Appl. Environ. Microbiol. 2005, 71, 3519-3523. [CrossRef] [PubMed]

63. De Maayer, P.; Anderson, D.; Cary, C.; Cowan, D.A. Some like it cold: Understanding the survival strategies of psychrophiles. EMBO Rep. 2014, 15, 508-517. [CrossRef] [PubMed]

64. Lee, Y.M.; Kim, G.; Jung, Y.-J.; Choe, C.-D.; Yim, J.H.; Lee, H.K.; Hong, S.G. Polar and Alpine Microbial Collection (PAMC): A culture collection dedicated to polar and alpine microorganisms. Polar Biol. 2012, 35, 1433-1438. [CrossRef]

65. Shivaji, S. Bacterial biodiversity, cold adaptation and biotechnological importance of bacteria occurring in Antarctica. Proc. Ind. Natl. Sci. Acad. USA 2017, 83, 327-352. [CrossRef] 
66. Pearce, D.A.; Newsham, K.; Thorne, M.; Calvo-Bado, L.; Krsek, M.; Laskaris, P.; Hodson, A.; Wellington, E.M. Metagenomic analysis of a southern maritime Antarctic soil. Front. Microbiol. 2012, 3, 403. [CrossRef] [PubMed]

67. Sjöling, S.; Cowan, D.A. High $16 \mathrm{~S}$ rDNA bacterial diversity in glacial meltwater lake sediment, Bratina Island, Antarctica. Extremophiles 2003, 7, 275-282. [CrossRef] [PubMed]

68. Dawid, W. Biology and global distribution of myxobacteria in soils. FEMS Microbiol. Rev. 2000, $24,403-427$. [CrossRef] [PubMed]

69. Bárria, C.; Malecki, M.; Arraiano, C.M. Bacterial adaptation to cold. Microbiology 2013, 159, $2437-2443$. [CrossRef] [PubMed]

70. Mojib, N.; Andersen, D.T.; Bej, A.K. Structure and function of a cold shock domain fold protein, CspD, in Janthinobacterium sp. Ant5-2 from East Antarctica. FEMS Microbiol. Lett. 2011, 319, 106-114. [CrossRef] [PubMed]

71. Jones, P.G.; Krah, R.; Tafuri, S.R.; Wolffe, A.P. DNA gyrase, CS7.4, and the cold shock response in Escherichia coli. J. Bacteriol. 1992, 174, 5798-5802. [CrossRef] [PubMed]

72. Severinov, K. RNA polymerase structure-function: Insights into points of transcriptional regulation. Curr. Opin. Microbiol. 2000, 3, 118-125. [CrossRef]

73. Storey, K.B.; Storey, J.M. Protein Adaptations and Signal Transduction; Elsevier: Amsterdam, The Netherlands, 2001; Volume 2, ISBN 9780444507594.

74. Chintalapati, S.; Kiran, M.; Shivaji, S. Role of membrane lipid fatty acids in cold adaptation. Cell. Mol. Biol. 2004, 50, 631-642. [PubMed]

75. Hunger, K.; Beckering, C.L.; Wiegeshoff, F.; Graumann, P.L.; Marahiel, M.A. Cold-induced putative DEAD box RNA helicases CshA and CshB are essential for cold adaptation and interact with cold shock protein B in Bacillus subtilis. J. Bacteriol. 2006, 188, 240-248. [CrossRef] [PubMed]

76. Shivaji, S.; Prakash, J.S. How do bacteria sense and respond to low temperature? Arch. Microbiol. 2010, 192, 85-95. [CrossRef] [PubMed]

77. Weber, M.H.; Marahiel, M.A. Coping with the cold: The cold shock response in the Gram-positive soil bacterium Bacillus subtilis. Philos. Trans. R. Soc. B 2002, 357, 895-907. [CrossRef] [PubMed]

78. Jain, N.K.; Roy, I. Effect of trehalose on protein structure. Protein Sci. 2009, 18, 24-36. [CrossRef] [PubMed]

79. Kandror, O.; DeLeon, A.; Goldberg, A.L. Trehalose synthesis is induced upon exposure of Escherichia coli to cold and is essential for viability at low temperatures. Proc. Natl. Acad. Sci. USA 2002, 99, 9727-9732. [CrossRef] [PubMed]

80. Phadtare, S. Recent developments in bacterial cold-shock response. Curr. Issues Mol. Biol. 2004, 6, 125-136. [CrossRef] [PubMed]

81. Rudolph, A.S.; Crowe, J.H.; Crowe, L.M. Effects of three stabilizing agents-proline, betaine, and trehalose-on membrane phospholipids. Arch. Biochem. Biophys. 1986, 245, 134-143. [CrossRef]

82. Weber, M.H.; Marahiel, M.A. Bacterial cold shock responses. Sci. Prog. 2003, 86, 9-75. [CrossRef] [PubMed]

83. Dersch, P.; Kneip, S.; Bremer, E. The nucleoid-associated DNA-binding protein H-NS is required for the efficient adaptation of Escherichia coli K-12 to a cold environment. Mol. Gen. Genet. 1994, 245, 255-259. [CrossRef] [PubMed]

84. Dorman, C.J. H-NS-like nucleoid-associated proteins, mobile genetic elements and horizontal gene transfer in bacteria. Plasmid 2014, 75, 1-11. [CrossRef] [PubMed]

85. La Teana, A.; Brandi, A.; Falconi, M.; Spurio, R.; Pon, C.L.; Gualerzi, C. Identification of a cold shock transcriptional enhancer of the Escherichia coli gene encoding nucleoid protein H-NS. Proc. Natl. Acad. Sci. USA 1991, 88, 10907-10911. [CrossRef] [PubMed]

86. White-Ziegler, C.A.; Davis, T.R. Genome-wide identification of H-NS-controlled, temperature-regulated genes in Escherichia coli K-12. J. Bacteriol. 2009, 191, 1106-1110. [CrossRef] [PubMed]

87. Mizushima, T.; Kataoka, K.; Ogata, Y.; Inoue, R.I.; Sekimizu, K. Increase in negative supercoiling of plasmid DNA in Escherichia coli exposed to cold shock. Mol. Microbiol. 1997, 23, 381-386. [CrossRef] [PubMed]

88. Simon, C.; Wiezer, A.; Strittmatter, A.W.; Daniel, R. Phylogenetic diversity and metabolic potential revealed in a glacier ice metagenome. Appl. Environ. Microbiol. 2009, 75, 7519-7526. [CrossRef] [PubMed]

89. Médigue, C.; Krin, E.; Pascal, G.; Barbe, V.; Bernsel, A.; Bertin, P.N.; Cheung, F.; Cruveiller, S.; D’Amico, S.; Duilio, A. Coping with cold: The genome of the versatile marine Antarctica bacterium Pseudoalteromonas haloplanktis TAC125. Genome Res. 2005, 15, 1325-1335. [CrossRef] [PubMed] 
90. Dalluge, J.J.; Hamamoto, T.; Horikoshi, K.; Morita, R.Y.; Stetter, K.O.; McCloskey, J.A. Posttranscriptional modification of tRNA in psychrophilic bacteria. J. Bacteriol. 1997, 179, 1918-1923. [CrossRef] [PubMed]

91. Pucciarelli, S.; Devaraj, R.R.; Mancini, A.; Ballarini, P.; Castelli, M.; Schrallhammer, M.; Petroni, G.; Miceli, C. Microbial consortium associated with the Antarctic marine ciliate Euplotes focardii: An investigation from genomic sequences. Microb. Ecol. 2015, 70, 484-497. [CrossRef] [PubMed] 